\title{
A Born Global Gradually Advancing Its Internationalization - a Case Study of Internationalization Process of a Small Tour Operator in a Niche Market
}

\author{
Karolina Nessel*
}

\begin{abstract}
Today much is already known about the internationalization patterns of small and medium enterprises (SMEs). However, the research has mainly focused on outward internationalization and more in manufacturing industry than in services (and hardly in the tourism industry). Thus, the paper undertakes an exploratory research in order to verify to what extent the common framework of analysis may explain an internationalization path of SMEs in the tourism sector. To this goal, a case study of a small tour operator in a niche market of weddings abroad in Poland is undertaken. The research seeks to match the firm's internationalization characteristics with considerations of two dominant theories of SME internationalization: stage models of gradual internationalization (so called behavioral models) and models of early and rapid internationalization (businesses called 'born globals' or 'international new ventures').

The main findings of the study are twofold. Firstly, even if the general framework of the analysis suits a case of a small tour operator well, still there is a need to adapt the general framework to industry features (in particular, in terms of organization capabilities). Secondly, a further research should also take into account heterogeneity of international activities (in terms of their antecedents and process). Even if a firm is born global, its further internationalization may well be incremental in nature. In particular, an early and rapid internationalization through imports may lead to a gradual internationalization through exports. The former may result from a proactive attitude, be strategy driven, and implied by characteristics of the market and product (well in lines with models of an early and rapid internationalization). The latter, however, may stem from a rather passive attitude with almost no resource commitment (more in lines with models of a gradual and slow internationalization). Keywords: SMEs, internationalization, stage models, behavioral models, born global firms, international new ventures, international entrepreneurship, tourism industry, tour operator, niche market.
\end{abstract}

* Karolina Nessel, Ph.D., Jagiellonian University, ul. S. Łojasiewicza 4, Kraków, Poland, karolina.nessel@uj.edu.pl. 


\section{Introduction}

We have a chance to live in a fast globalizing and shrinking world. Advances in information, telecommunication, and transport technologies combined with a political will of economic liberalization after the world war two have swept many age-old barriers for entrepreneurs from a vast majority of the globe. The political and economic distances for business have shrunk and new vast markets have opened up. Thus reconfigured space has been filled with regularly intensifying international flows of capital, goods, services, technology, and information propelled by profit maximizing firms exploiting new opportunities. Corporations and individual entrepreneurs internationalizing their operations have been making the economic globalization of our world - with all the costs and benefits of the process.

Not surprisingly, the process of internationalization has been widely studied by scholars. In fact, it was already Adam Smith, the founding father of economics, who wondered why individuals/firms/nations trade with each other. His idea of an absolute advantage (Smith, 1976) has been later developed into the concept of a comparative advantage and elaborated by other classical and neoclassical economists (Ricardo, 1817; Ohlin, 1933). The modern economics has completed the picture with theories of international product life cycle (Vernon, 1966), transaction costs (Williamson, 1973), monopolistic advantage (Caves, 1971; Hymer, 1976), and finally with the eclectic paradigm for international production (Dunning, 1981).

Yet, the abovementioned theories are better in explaining an internationalization of nations and big multinational corporations than crossborder activities of small and medium enterprises (SMEs). Furthermore, most of the literature has been focused on firms manufacturing and trading goods rather than services. Clearly, the internationalization process of service companies has some specificities due to the simultaneity of production and consumption. The issue becomes even more specific in the case of tourism services with the (non local) mobility of the markets.

Hitherto, the internationalization of the tourism services by SMEs has been relatively neglected and clearly in need of more solid theoretical underpinnings (Shaw and Williams, 2004, Agndal and Elbe, 2007, Hjalager, 2007, Williams and Shaw, 2011). The question is of importance as the globalization is widely acknowledged to deeply influence the tourism industry (Lanfant, 1995; Fayed and Fletcher, 2002; Johnson and Vanetti, 2005).

Therefore, the paper undertakes an exploratory research to verify to what extent the common framework of analysis may explain an internationalization path of SMEs in the tourism sector. To this goal, a case study of a small tour operator in a niche market of weddings abroad in Poland is undertaken. The research seeks to match the firm's internationalization characteristics 
with considerations of two dominant theories of SME internationalization: stage models of gradual internationalization (so called behavioral models) and models of early and rapid internationalization (businesses called 'born globals' or 'international new ventures').

This paper is organized as follows. The next part of the paper reviews the main theoretical approaches to the small business internationalization. The conceptual framework of analysis is presented in the third part, while the methodology makes the fourth section of the paper, followed by the case study. The final section concludes and proposes future research lines.

\section{Literature review}

The section briefly reviews the research on two main patterns of SME internationalization and propositions of a holistic model integrating conclusions from the two approaches.

\section{Stage models of internationalization}

Research on SME internationalization began in 1975 when Johanson and Wiedersheim proposed a model in which a firm starts operations in its domestic market and only later gradually engages in foreign markets (Johanson and Wiedersheim, 1975). The engagement in transnational activities grows as the firm acquires international experience, which is a reinforcing phenomenon (Johanson and Vahlne, 1977, 1990; Bilkey and Tesar, 1977; Cavusgil, 1980; Reid, 1981).

Thus, a couple of stages in internationalization process may be indicated. The literature is abundant in different categorization of stages (e.g. Bilkey and Tesar, 1977; Czinkota, 1982; Cavusgil, 1984; Andersen, 1993, McDougall, Shane, and Oviat, 1994; Moini, 1995, Leonidou and Katsikeas, 1996, 1997; Coviello and McAuley, 1999), but in general the researchers follow the establishment chain proposed by the Uppsala internationalization process model (Johanson and Vahlne, 1977). In the initial stage firms operate only in domestic market, with no international activity. Then first, often unsolicited occasions of irregular imports or exports appear. These occasions allow for an accumulation of experience, know-how, information, and contacts and give courage to engage in a regular export/import activity in near foreign markets. Exports may be initially conducted through intermediaries (agents, licensing, franchising) and later - if successful- directly by the company itself (sales subsidiaries). The direct presence in foreign markets decreases the perceived distance (so called psychic distance) and supports a deeper involvement and production factors relocation (eventually an overseas manufacturing subsidiary). The psychic distance corresponds to the liability of foreignness, a disadvantage of foreign firms in relation to domestic ones when competing 
in a national market. According to the initial Uppsala model, the psychic distance decreases with market knowledge and market commitment (the later being a function of the size of the inflexible investment). As learning and commitment building take time, an internationalizing firm increases its commitment in a given market and moves into more distant and risky ones only progressively.

The successive work on business networks has proved the utility of network approach in explaining the internationalization process, especially of SMEs, and particularly in an early phase of their engagement in foreign markets (Coveillo and Munro 1995, 1997; Welch and Welch 1996; Martin, Swamintharn and Michell 1998; Chetty and Blankenbourg Holm, 2000; Ellis 2000). Some studies have shown the importance of relationships with the key partners in the process of internationalization (Sharma and Johanson 1987; Bonaccorsi 1992). These relationships often develop through social exchange process between key managers, which results in greater trust and knowledge, and finally greater mutual commitment (Dwyer, Schurr and Oh, 1987; Anderson and Wietz 1992). Being an insider of a network present in a foreign market decreases psychic distance and facilitates foreign expansion. Thus the updated version of Uppsala model places the liability of being an outsider at the roots of uncertainty, and hence makes it a very important factor impeding a successful internationalization (Johanson and Vahlne, 2009). Accordingly, being an insider facilitates acquiring knowledge and recognition/creation of opportunities, which leads to decisions and commitments relating to relationships and trust building, as well as to further learning. This way, there is a rise in the foreign markets commitment plus a change in the network position. The latter in turn determines the further potential for knowledge accumulation and opportunities recognition.

The stage theories of internationalization have been classified as behavioral, while they suggest that firms internationalize in a deliberate, incremental way learning from markets and networks and gradually increasing their commitment to these. This view has been challenged by an important evidence of growing number of firms international since their beginnings.

\section{Early and rapidly internationalizing firms}

In the last thirty years, as business networks and alliances, service and Internet-driven economy gained importance, the pool of available managerial skills worldwide enlarged, and homogenization of many markets advanced, conditions for internationalization of SMEs have radically improved. The pace of internationalization of some of SMEs has accelerated dramatically, and a new group of early and rapidly internationalizing firms (ERIFs) has emerged 
(in the literature these firms are usually called 'born-globals' or 'international new ventures', but a few other terms are also used**).

ERIFs are internationally oriented since their inception and often extensively internationally involved, while their management perceive the world as their marketplace from the outset. Naturally, this is in contrast to the stage model of gradual internationalization. For the ERIFs activities on foreign markets (often simultaneously on many distant ones) are fundamental for their competitive advantage, internationalization of their operations being at the core of their business model. Their internationalized activity may be of different form (outward or inward - Hessels, 2008), even if the most widely used concept of an early and rapidly internationalizing firm is based on their superior exports performance in multiple countries (Rennie, 1993; Oviatt and McDougall, 1994, 1997; Knight and Cavusgil, 1996; Autio, Sapienza and Almeida, 2000; Madsen, Rasmussen, and Servais, 2000; Moen, 2002; Moen and Servais, 2002).

Main developments to the basic model of ERIFs (originally proposed by Rennie, 1993, McDougall et al., 1994; Oviatt and McDougall, 1995), have searched to determine factors accelerating the pace of internationalization of small businesses operating usually under important constraints of scarce financial, human and tangible resources. Besides new market conditions and technological developments, studies have focused mainly on resources, knowledge and capabilities of the entrepreneur, managers and the organization itself. In this context, the research has underlined a prior international experience of the founder and managers (Oviatt and ougall, 1997; Madsen and Servais, 1997; Anderson and Wictor, 2003), their managerial capacities (Zahra, 2005), learning orientation and a global mindset (Weerawardena, Mort, Liesch, and Knight, 2007), innovative culture and organizational capabilities (Knight and Cavusgil, 2004), and extended international personal networks (Chetty and Campbell-Hunt, 2003, 2004; Oviat and McDougall, 2005; Coviello 2006).

The study of ERIFs is a subset of the research in international entrepreneurship in its cross-border activity perspective. Oviatt and McDougall have defined the international entrepreneurship as: "(...) the discovery, enactment, evaluation, and exploitation of opportunities - across national borders - to create future goods and services" (Oviatt and McDougall,

** Various definitions of the phenomenon are employed by researches: 'born globals' (Rennie, 1993; Knight and Cavusgil, 1996; Madsen and Servais, 1997; Aspelund and Moen, 2001; Sharma and Blomstermo, 2003; Gabrielsson and Kirpalani, 2004); 'international new ventures' (McDougall et al., 1994, 2003; Oviatt and McDougall, 1994, 1997); 'born international' (Kundu and Katz, 2003); 'new entrepreneurial ventures' (Brettel et al., 2009); 'global smaller firm' (Dimitratos et al., 2010); 'instant exporters' (McAuley, 1999); 'early internationalizing firms' (Rialp et al. 2005a); 'global start-ups' (Oviat and McDougall, 1995); 'micromultinationals' (Dimitratos et al., 2003); 'instant internationals' (Fillis, 2001); 'instant exporters' (McAuley, 1999). In this study, the term of 'early and rapidly industrializing firms' (ERIFs) is used (following Madsen; 2013) in order to encompass various different but overlapping expressions describing the phenomenon. 
2005, p.540). The academic literature presents the entrepreneurship as creation of a new economic activity (Davidsson, Delmmar and Wiklund, 2006) upon an opportunity recognition and exploitation (Kirzner 1979). Yet, entrepreneurship is not only about innovation, it also involves risk-taking and pro-activeness (Covin and Slevin, 1989; Lumpkin and Dess, 1996). The international dimension of entrepreneurship in the context of ERIFs is present in a creation of new international venture (McDougall, 1989) or a new international activity of an established SME (Lu and Beamish, 2001). Clearly internationalization is entrepreneurial as it requires accepting a higher level of risk than domestic market operations (Lu and Beamish, 2001; Leiblein and Reuer, 2004), demands an innovation in choosing markets, forms of entry and adapting products (Zahra et al., 2001; Leiblein and Reuer, 2004), stems from a proactive attitude of generating growth and wealth through strategic exploitation of foreign markets (Lumpikn and Dess, 1996; Zahra, Kuratko and Jennings, 1999).

The research in international entrepreneurship has been a valuable input into understanding internationalization of SMEs - either gradually or at inception. As it has focused mainly on antecedents of the process of SME internationalization, a lot is already known about facilitating and inhibiting factors at the micro-level. In general, these factors may be categorized into three groups: individual entrepreneur-specific factors, firm-specific factors, environment-specific factors (Ford and Leonidou, 1991; Antoncic and Hisrich, 2000; Ibeh, 2006). This classification may be useful in constructing a holistic model of SME internationalization.

\section{Towards a holistic model of SME internationalization}

There has been a clear need to integrate different research conclusions on the SME internationalization. Or, some researchers have argued that besides firms entering foreign markets incrementally and firms international already at founding, there are also firms starting their international expansion in a progressive way, but then accelerating enormously after a critical event (so called 'born-again global' Bell at al., 2003). This would suggest that stage models and models of ERIFs are just extreme points of a continuum. Besides, Madsen and Servais (1997) argued that even if ERIFs internationalize in a different way at the manifest level, they are not necessarily different from other firms evolving more in lines with stage models. Thus, the both theories may be more complementing than competing.

One of the propositions of such an integrated model was presented by Fletcher (2001), who divided international activities into three forms: outward (e.g. exports, outward foreign direct investment), inward (e.g. imports), and linked (e.g. strategic alliances). This categorization 
underscores a possibility of initial internationalization other than exports. Moreover, according to Fletcher, the engagement in one of these activities influences the probability of taking on other activities (e.g. an inward driven internationalization may lead to exports and vice versa), and linked activities may be driven by outward or inward internationalization. This interaction, combined with internal and external factors determines not only speed but also direction of internationalization process (as there is also a chance of de-internationalization). The same factors influencing outward forms of internationalization determine as well inward and linked forms.

Integrating Fletcher's framework with conclusions from international entrepreneurship (in particular the work of Rialp, Rialp, Urabano, and Vaillant, 2005), the holistic model of SME is presented in Figure 1.

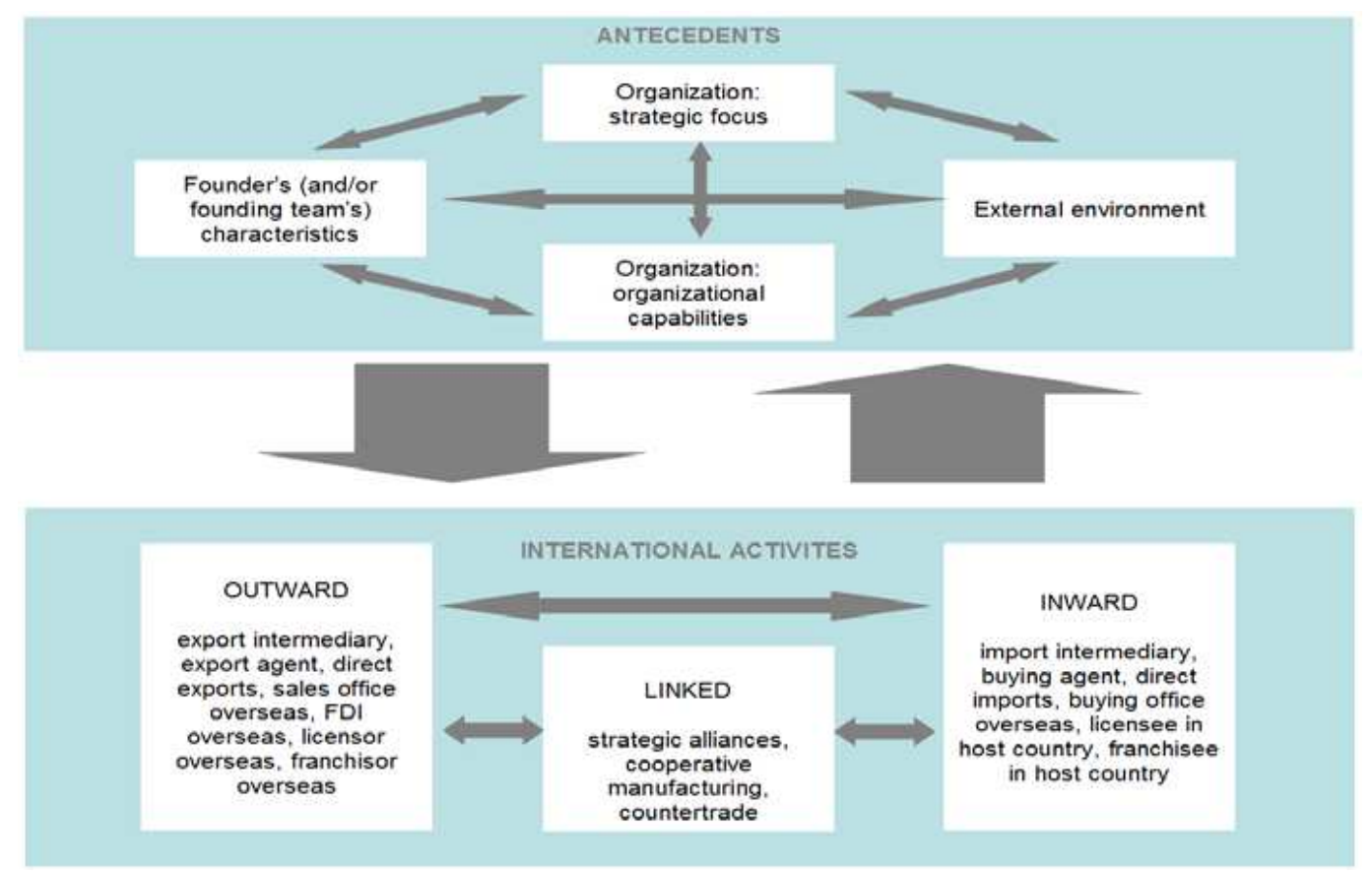

Figure 1. A holistic approach to internationalization process and its antecedents

Source: Author's adaptation of Fletcher (2001) and Rialp et al. (2005).

In Figure 1, different than in the original Fletcher's model, internal and external factors have been categorized into four subcategories proposed by research on international entrepreneurship. The goal of the modification is to underscore the key role of entrepreneur's characteristics in a small firm (as the paper is devoted to a case study of a micro firm). 


\section{Conceptual framework}

Based on the above discussion, a conceptual framework is presented where the four main subcategories of factors determining the pace of internationalization are explored. The goal is to summarize expected forces pushing firms toward one of the two extreme internationalization patterns (gradual versus rapid internationalization). The three dimensions (founder's characteristics, organizational capabilities, strategic focus) are a slight adaptation of the framework proposed by Rialp et al. (2005), where a possibility of internationalization through imports has been included (while the original framework was proposed only for exporting firms). The attributes of the fourth category (external environment) result from the analysis of Madsen and Servais (1997). In Table 1 the four categories and their matching attributes are presented.

Table 1. Excepted factors associated with gradual internationalization versus early and rapid internationalization

\begin{tabular}{|c|c|c|}
\hline Attributes & Early and rapid internationalization & Gradual internationalization \\
\hline \multicolumn{3}{|c|}{ Founder's (and/or founding team's) characteristics } \\
\hline $\begin{array}{l}\text { Managerial } \\
\text { vision }\end{array}$ & Global from inception. & $\begin{array}{l}\text { International markets to be } \\
\text { used gradually after a significant } \\
\text { development of domestic } \\
\text { markets base. }\end{array}$ \\
\hline $\begin{array}{l}\text { Prior } \\
\text { international } \\
\text { experience }\end{array}$ & $\begin{array}{l}\text { High degree of previous international } \\
\text { experience. }\end{array}$ & $\begin{array}{l}\text { Irrelevant or low degree } \\
\text { of previous experience in } \\
\text { international issues. }\end{array}$ \\
\hline $\begin{array}{l}\text { Managerial } \\
\text { commitment }\end{array}$ & $\begin{array}{l}\text { High and dedicated commitment with } \\
\text { early internationalization efforts and } \\
\text { challenges. }\end{array}$ & $\begin{array}{l}\text { General commitment } \\
\text { with objectives and task } \\
\text { but not directly related to } \\
\text { internationalization. }\end{array}$ \\
\hline Networking & $\begin{array}{l}\text { Stronger use of both personal and } \\
\text { business networks at the local and } \\
\text { international level. Crucial to firm early, } \\
\text { rapid, and successful global market } \\
\text { reach. }\end{array}$ & $\begin{array}{l}\text { Loose network of personal } \\
\text { and business partners (only } \\
\text { those fitting a path of gradual } \\
\text { internationalization). }\end{array}$ \\
\hline \multicolumn{3}{|c|}{ Organizational capabilities } \\
\hline $\begin{array}{l}\text { Market } \\
\text { knowledge } \\
\text { and } \\
\text { commitment }\end{array}$ & $\begin{array}{l}\text { High from the very beginning due to } \\
\text { superior internationalization knowledge } \\
\text { at inception. }\end{array}$ & $\begin{array}{l}\text { Slowly growing with previously } \\
\text { accumulated domestic and } \\
\text { foreign market knowledge. }\end{array}$ \\
\hline $\begin{array}{l}\text { Intangible } \\
\text { assets based } \\
\text { on knowledge } \\
\text { management }\end{array}$ & $\begin{array}{l}\text { Unique intangible assets (based usually } \\
\text { on knowledge management processes) } \\
\text { are critical for early internationalization } \\
\text { purposes. }\end{array}$ & $\begin{array}{l}\text { Availability and role of } \\
\text { intangible assets are less } \\
\text { important for successful gradual } \\
\text { internationalization. }\end{array}$ \\
\hline
\end{tabular}




\begin{tabular}{|c|c|c|}
\hline $\begin{array}{l}\text { Value creation } \\
\text { sources }\end{array}$ & $\begin{array}{l}\text { High value creation through product } \\
\text { differentiation, leading-edge technology } \\
\text { products, technological innovativeness, } \\
\text { and quality leadership. }\end{array}$ & $\begin{array}{l}\text { Less innovative and leading edge } \\
\text { nature of its products resulting } \\
\text { in a more limited value creation } \\
\text { capability. }\end{array}$ \\
\hline \multicolumn{3}{|c|}{ Strategic focus } \\
\hline $\begin{array}{l}\text { Extend and } \\
\text { scope of } \\
\text { international } \\
\text { strategy }\end{array}$ & $\begin{array}{l}\text { A niche-focused, highly proactive } \\
\text { international strategy developed in } \\
\text { geographically spread lead markets } \\
\text { around the world from inception. }\end{array}$ & $\begin{array}{l}\text { A more reactive and less niche- } \\
\text { focused international strategy. } \\
\text { International markets will, at } \\
\text { best, be developed serially and } \\
\text { in order of psychic distance. }\end{array}$ \\
\hline $\begin{array}{l}\text { Selection, } \\
\text { orientation, } \\
\text { and } \\
\text { relationships } \\
\text { with } \\
\text { customers and } \\
\text { suppliers } \\
\end{array}$ & $\begin{array}{l}\text { Narrowly-defined customer/suppliers } \\
\text { groups with strong customer } \\
\text { orientation. }\end{array}$ & $\begin{array}{l}\text { In the hands of intermediaries } \\
\text { in the early stages of } \\
\text { internationalization. }\end{array}$ \\
\hline $\begin{array}{l}\text { Strategic } \\
\text { flexibility }\end{array}$ & $\begin{array}{l}\text { Extreme flexibility to adapt to rapidly } \\
\text { changing external conditions and } \\
\text { circumstances. }\end{array}$ & $\begin{array}{l}\text { Limited flexibility to adapt } \\
\text { to rapidly changing external } \\
\text { conditions and circumstances. }\end{array}$ \\
\hline \multicolumn{3}{|c|}{ External environment } \\
\hline $\begin{array}{l}\text { Perceived } \\
\text { external } \\
\text { barriers }\end{array}$ & $\begin{array}{l}\text { Low perceived external barriers to } \\
\text { internationalization. }\end{array}$ & $\begin{array}{l}\text { High perceived external } \\
\text { barriers to internationalization, } \\
\text { decreasing gradually with } \\
\text { trans-border successes or with } \\
\text { a positive evolution of the } \\
\text { external environment. }\end{array}$ \\
\hline $\begin{array}{l}\text { Perceived } \\
\text { external } \\
\text { incentives }\end{array}$ & $\begin{array}{l}\text { Important perceived market, industry- } \\
\text { and government- based incentives (i.a. } \\
\text { accessible public support, significant } \\
\text { internationalization of the market, } \\
\text { high specialization of the firm, strong } \\
\text { need for economies of scale and short } \\
\text { product life cycle). }\end{array}$ & $\begin{array}{l}\text { Weak perceived market-, } \\
\text { industry-, and government- } \\
\text { based incentives, decreasing } \\
\text { gradually with trans-border } \\
\text { successes or with a positive } \\
\text { evolution of the external } \\
\text { environment. }\end{array}$ \\
\hline
\end{tabular}

Source: Author's adaption of Rialp et al. (2005) and Madsen and Servais (1997) .

The above overview of attributes of the two extreme internationalization patterns is the one often applied in the literature. However, these attributes are usually used in cases of export-led internationalization, more often in manufacturing than in service sector (and hardly in case of the tourism industry). To verify if there is really a need to adapt these patterns and theories to the tourism industry, an internationalization path of a small tour operator in Poland is analyzed in the further part of this study. 


\section{Methodology}

In order to understand how the internationalization pattern of a tourism company fits the predictions of the two theories, a qualitative research in the form of a single case study was applied. The qualitative methodology permits the researcher to get at the inner experience of participants and establish a personal contact with them (Strauss and Corbin, 1990), which is particularly valuable in the case of research on small business where the entrepreneur's personal characteristics and attitude are primordial. The case study approach was selected due to an exploratory character of the study, and because it allows for an in-depth investigation of an event, activity, process or individual bounded by time and activity (Creswell, 2003). A limitation to a single case study was chosen as it allows for an even deeper investigation of a phenomenon in order to provide a rich description and understanding (Walsham, 1995), especially when the research questions are 'how' and 'why' (Yin, 1994).

The sample selection was based on criteria following from the above discussed theories of SME internationalization (a small business actively involved in an internationalization process), the goal of the study (an SME in the tourism sector) and a pragmatic criterion of data availability. The empirical investigation was undertaken in July 2013 during two 3 hour-long meetings with the founder of the firm. The information was gathered through a semistructured interview and a short survey. Next, a pattern matching of the data collected with the considerations of the two theories was conducted.

Another methodological issue to be decided upon was the question of empirical classification of the chosen firm as an early and rapidly internationalizing firm or a gradually internationalizing one. In fact, even if the literature is quite unanimous when conceptualizing the idea of early and rapidly internationalizing firms (usually following the definition proposed by Oviatt and McDougall, 1994), there is still a lot of heterogeneity when it comes to operationalizing the idea in the empirical research (Madsen, 2013). The most useful dimensions used in the empirical studies are: extent, speed and scope of international development (as suggested by Zahra and George, 2002). However, these dimensions are given various economic values and different thresholds by researches. Following the methodology proposed by Madsen (2013), in this study the dimensions will be operationalized according to the criteria in Table 2. 
Table 2. Operationalization of empirical criteria used for determining early and rapidly internationalizing enterprises

\begin{tabular}{ll}
\hline Speed & an international activity within 3 years after its foundation \\
\hline \multirow{2}{*}{ Scope } & $\begin{array}{l}1 \text { or } 2 \text { activities coordinated across borders within } 3 \text { years after its foundation } \\
\text { (i.e. sourcing, production, sales and marketing, services activities) } \\
\text { and } 4 \text { foreign countries outside its continent }\end{array}$ \\
\hline \multirow{2}{*}{ Extent } & $\begin{array}{l}25 \% \text { of sales within } 3 \text { years after its foundation } \\
\text { or } 25 \% \text { of sourcing within } 3 \text { years after its foundation }\end{array}$ \\
\hline
\end{tabular}

Source: Madsen (2013).

\section{Events - the case study}

The firm chosen to verify the applicability of the stage models and born global models to the internationalization processes in the tourism sector was 5 Events - a small tour operator in Poland operating mainly in a niche market of weddings abroad.

\section{Events - the entrepreneur}

5 Events was founded in 2009 by Lidia Wandas (LW) who was 27 years old then. At that time she had already accumulated an important education and practical experience in the tourism business, as she had obtained an MBA in Tourism Management from Jagiellonian University in Cracow, had effectuated a few internships and had worked for some Polish tour operators (as well in Poland as a product specialist, and abroad as a resort representative in Greece or a travel courier). It must be also mentioned that LW grew up in an entrepreneurial family, and her mother works in the MICE industry. In these settings it had always been clear for LW that she was going to work in a tourism business. She is a hard-working person, striving for perfection, evidently entrepreneurial but also very risk averse (according to her own judgment). Her interpersonal skills are very well developed and she is good at starting and sustaining personal relationships as well as at business negotiations. Her business ambition is to fortify the position of her firm 5 Events as a leader in the actual market by means of a high quality offer.

\section{Events - the business}

5 Events is a leading Polish tour operator specialized in weddings abroad. The firm offer is directed mainly to Polish clients wishing to get married in a foreign destination and usually includes formalities related to the ceremony (demanded by a registry office or a church), organization of the ceremony itself (an official part and a reception), as well as transport and accommodation - for the bride and groom and their guests. 5 Events also offers romantic tours and 
package holidays. The main wedding destinations are Greece, Italy, Canary Islands, Croatia, Indonesia, Thailand, Dominican Republic. Besides, the firm arranges weddings in Poland for foreigners (e.g. in a salt-mine).

This microenterprise is run mainly by the founder herself with one full time employee, and helped recently by a trainee. Naturally, the firm uses a lot of outsourcing at home and in the destinations. Moreover, it draws heavily on products (accommodation and transport) prepared by other tour operators (acting in fact as a travel agency in this case).

Actually, in 2009 the business started as a typical travel agency, offering products of three big tours operators, with a rented office in the center of Cracow. The beginnings were difficult, as there are plenty of other travel agencies selling the same products and the competition is fierce. The founder was aware of the need of an offer differentiation and bet on weddings abroad. This way, in 2010 first weddings were organized and progressively the business model has been modified. Today agency sales still represent more than a half of the turnover, but in quasi totality they are part of wedding packages. As the number of individual transactions is smaller than in a standard travel agency, the rental of the costly office has been abandoned, and the contact takes place through Internet, phone, and in cafes. Clients come from all over the country, and often the founder travels to meet them personally in their locations, which also constitutes a part of a marketing strategy. Today the business is in a very good financial condition, there has been an impressive rise in the turnover, the offer is being expanded, and new markets are being considered.

The expansion of the firm is facilitated by a recent and important growth of this niche market. In Poland, there are four key players in this market, all of them are small businesses ( 5 Events being one of them). Their offer is rich in destinations, partly in a direct competition. Yet, in some cases the companies cooperate acting as agents for chosen products of others. There is also some competition coming from the destinations (by companies or individual entrepreneurs) offering weddings in a given location. As the entry barriers into the market are not high, there is a probability of new players (e.g. big Polish tour operators including the product into their offer, or foreign agencies specialized in the product entering the Polish market through Internet sales). Hence, 5 Events is in need of a further offer development to fortify its actual reputation and market position.

\section{Events - the internationalization process}

In 2009, the business started as a travel agency, which (even if it may be classified as indirect imports), was hardly an international activity, as it required contacts only with Polish clients and Polish suppliers. Things changed 
radically in 2010, when the firm entered the market of weddings abroad. This activity requires a direct contact with foreign partners - mainly suppliers of services: public servants (or priests) engaged in weddings ceremonies, owners of wedding spaces, organizers of wedding receptions. It also involves frequent travels to choose the suppliers and to survey and coordinate the ceremonies.

The first wedding took place in Tenerife (Spain) in 2010 and was induced by a demand from an acquainted couple. Its success gave courage to engage more into the activity and an official offer was prepared for the season 2011 including Tenerife (Spain), Santorini and Crete. The Greek destinations were chosen while LW had worked there as a resort representative.

Next offers were a result of three factors: clients' demand, formal possibilities (as in many destinations the weddings of non residents are not permitted), and, last but not least, possibilities to outsource some of the organizational requirements to consultants residing in the destinations. The latter has been necessary, as the number of destinations and clients grew, and the entrepreneur could not physically be present at each one personally (which was the case at the beginning). Today 5 Events collaborates with six consultants in destinations, but LW still attends personally ceremonies in at least one destination, and travels a lot to arrange new offers. Few are the countries where an offer may be prepared without a local presence of the firm's representative - often formal procedures are quite complicated, and a direct presence is essential to manage the contact with officials responsible for the procedures and the ceremony itself. In this perspective, the main entry barrier into this activity is the know-how of the procedures and good contacts with the local officials. It has to be secured either by LW herself, or by her representative. Since a wedding is naturally an event of an exceptional importance to clients, and as LW attaches great importance to the quality of the services offered, no room for an imperfection and improvisation is left, and the representatives and suppliers must be trustworthy. Thus, the pace and direction of the offer expansion in the segment of weddings abroad (and thus of internationalization of the business) was determined also by the availability of the right local consultants. In the case of church weddings, sometimes a presence of Polish speaking priest is indispensable. In some destinations LW has drawn on her earlier personal and professional relations, in some cases she has got in touch with the right people during workshops organized for Polish travel agencies, and in others the contact has been established through the intermediary of her direct current business relationships.

Arranging the wedding offer in consecutive destinations, LW has been developing her business network and exploring the foreign locations. 
Consequently, in 2011 she was able to offer her first own package holidays in Santorini (Greece).

In the meantime, the firm has also built its offer of weddings in Poland for foreign couples and presented it in the Internet. Already in 2011, the first couple from Sweden got married in the Salt Mine in Wieliczka.

The contact with foreign clients and the know how of the foreign localities have inspired the founder to construct an offer for weddings in Rhodes (Greece) for other clients than from Poland. Currently, as of 2013, the website in English is under construction and will be ready ahead of the next wedding season. In fact, weddings abroad are quite popular among the Brits. Other products in preparation are wedding packages for Poles in Kenya and Tanzania and ideas of a few others (e.g. in United Arab Emirates) are waiting in line.

Plainly, 5 Events started its transnational activity through an inward internationalization. Also today, the firm's international involvement means mainly resource seeking (searching for new destinations to market). Still, the inward internationalization is parallel to a slowly developing export performance (weddings for foreigners in Poland). Moreover, the firm prepares its offer of weddings abroad for foreigners, which means a greater engagement also as a market seeker and a greater outward orientation. In this case, the inward rapid internationalization is leading to the gradual outward internationalization. Clearly, 5 Events, even if already very engaged in the transnational activities, has much room for further internationalization and has already started to advance on this path. In the case of the firm, the different international activities reinforce themselves collaborating on Fletcher's model (Fletcher, 2001).

\section{Events - the empirical type of internationalization}

Three years after its founding, in 2012, 5 Events was engaged directly in trans-border operations when organizing weddings ceremonies abroad, own package holidays abroad, and foreign weddings in Poland. The first two categories are of direct import nature, the last one is exports of services. The three activities made almost 40\% of the total turnover in 2013 (Figure 2). However, due to the differences in margins, it equaled roughly $60 \%$ of value added of the firm. 


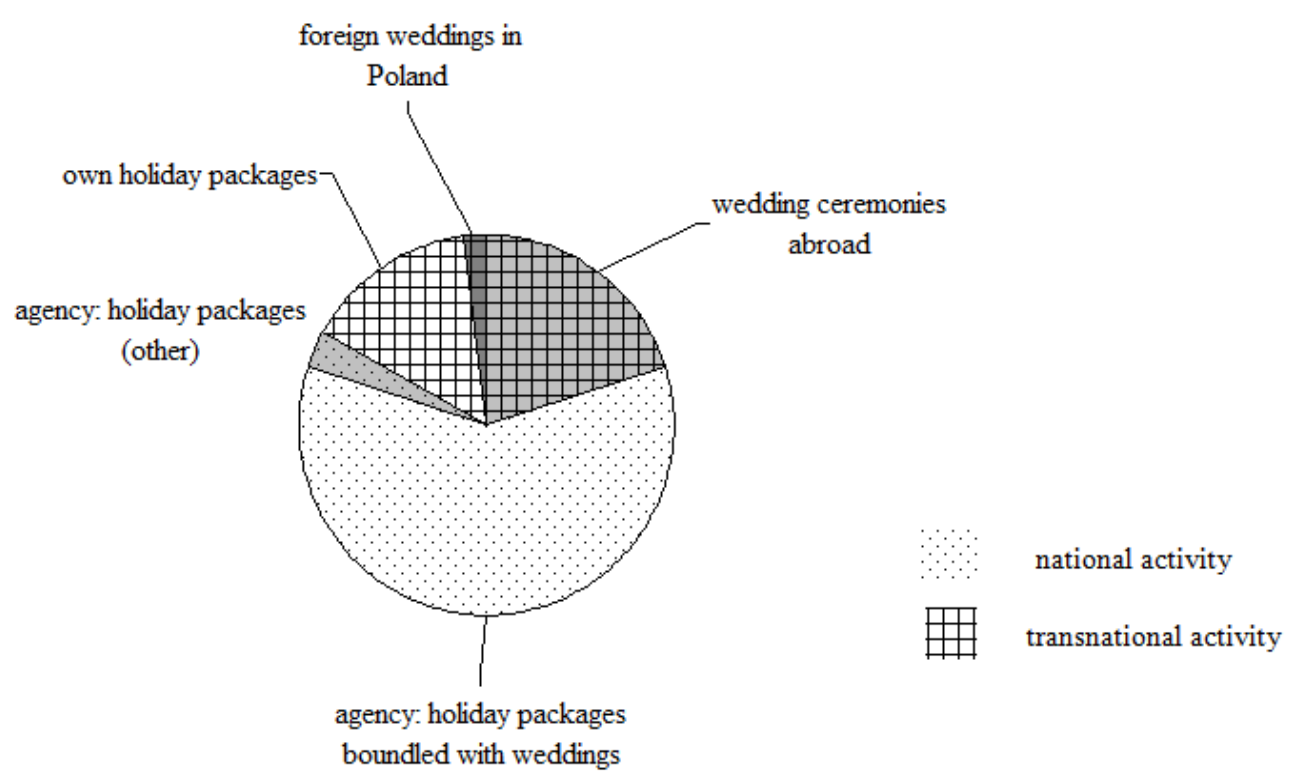

Figure 2. 5 Events - turnover by activity in 2012, rough estimations (percentage share)

Source: 5 Events.

Clearly, at the moment, the firm was mainly sourcing abroad (approximately $35 \%$ of its sales), in 7 principal markets.

Taking into account the foreign sales of weddings in Poland to foreigners, we could classify the 5 Events as a 'born global firm', while neglecting this activity (as it generated only 3\% sales in 2012) would make the firm a 'born international sourcer' according to the literature on born globals and Madsen's classification (Madsen, 2013). Intuitively the latter categorization suits the actual situation of the firm in 2012 better. Simultaneously, the firm's presence through the sourcing in at least 7 markets (of which 3 are in other continents) makes it fall into the category 'import start-up' according to the literature on international new ventures and Madsen's classification (Madsen, 2013).

Whatever exact subcategory classification, there is no doubt, that 5 Events fulfils the criteria mostly used in the empirical research to be considered as an early and rapidly internationalizing firm. Thus, one would expect that its internationalization process matches the attributes of ERIF theories presented earlier in this paper.

5 Events - the pattern matching with the 2 main theories of internationalization

The theoretical replication consists on examination of key differences and similarities of a given case with the theory considerations. In this research, 
the goal is to check to what extend 5 Events internationalization is in line with standard considerations of ERIF theories. TABLE 2 presents 5 Events internationalization antecedents and evaluate them on the 1-5 rating scale, where 1 is a typical gradually internationalizing firm (GIF) and 5 is a typical early and rapidly internationalizing firm (ERIF).

Table 2. Pattern matching analysis of 5 Events

\begin{tabular}{|c|c|}
\hline $\begin{array}{l}\text { Attributes and } \\
\text { their evaluation }\end{array}$ & 5 Events \\
\hline & under's (and/or founding team's) characteristics \\
\hline $\begin{array}{l}\text { Managerial } \\
\text { vision }\end{array}$ & \multirow{3}{*}{$\begin{array}{l}\text { At the very inception in } 2009 \text { there were no immediate plans for own } \\
\text { transnational activity, as the firm started as a typical travel agency. } \\
\text { However, the entrepreneur realized very soon the need for the product } \\
\text { differentiation in order to survive the fierce competition in the market. } \\
\text { Since } 2010 \text { the direct trans-border activity has been the principal driver } \\
\text { for the company's development. }\end{array}$} \\
\hline 12345 & \\
\hline ERIF & \\
\hline $\begin{array}{l}\text { Prior } \\
\text { international } \\
\text { experience }\end{array}$ & \multirow{3}{*}{$\begin{array}{l}\text { LW had had an important earlier international experience, including } \\
\text { the experience in the tourism sector. Her previous internships and } \\
\text { jobs gave her not only knowledge about some destinations but also } \\
\text { some valuable relationships (even today an important part of the } \\
\text { business are weddings in Greece, where she had worked as a resort } \\
\text { representative). LW had also traveled abroad a lot as an excursion } \\
\text { courier. She speaks English and some Greek. }\end{array}$} \\
\hline $123 \quad 3 \quad 45$ & \\
\hline & \\
\hline $\begin{array}{l}\text { Managerial } \\
\text { commitment }\end{array}$ & \multirow{3}{*}{$\begin{array}{l}\text { Till } 2013 \text { the whole business was managed by LW herself (and the } \\
\text { consultants in the destinations). Since } 2013 \text { and employment of } 1 \\
\text { employee and } 1 \text { trainee, LW has focused on relationships with clients } \\
\text { and offer development (new destinations for weddings, strengthening } \\
\text { relationships with foreign suppliers, marketing products to foreign } \\
\text { clients). }\end{array}$} \\
\hline $\begin{array}{lllll}1 & 2 & 3 & 4 & 5\end{array}$ & \\
\hline ERIF & \\
\hline Networking & \multirow{3}{*}{$\begin{array}{l}\text { The personal and business relationships have been one of key factors } \\
\text { determining the offer. Or, in some destinations right contacts with } \\
\text { local officials, Polish speaking priests, trustworthy consultants are of } \\
\text { a primordial importance. Still, in some other locations, weddings may } \\
\text { be arranged without any previous personal or business relationships. } \\
\text { When searching for partners WL uses mainly her personal and informal } \\
\text { business network. Nevertheless, some new potentially interesting } \\
\text { contacts have been established also through participation in official } \\
\text { workshops for tour operators. Even if LW finds herself averagely active } \\
\text { in initiating the new relationships, her business network has grown by } \\
300 \% \text { since } 2009 \text {. }\end{array}$} \\
\hline $\begin{array}{ccccc}1 & 2 & 3 & 4 & 5 \\
\text { GIF } & & & & \text { ERIF } \\
\end{array}$ & \\
\hline & \\
\hline
\end{tabular}




\section{Organizational capabilities}

$\begin{aligned} & \text { Market } \\
& \text { knowledge } \\
& \text { and commitment }\end{aligned}$
\begin{tabular}{|lllll|}
\hline 1 & $\mathbf{2}$ & 3 & 4 & 5 \\
GIF & & & ERIF \\
\hline
\end{tabular}

Today 5 Events has an important market knowledge about the formalities and procedures of wedding ceremonies in all the destinations available in its offer. The same concerns own package holidays offered in a few destinations. Weeding receptions in some locations, when arranged directly by the firm also require an extensive knowledge of local markets (which is not the case if they are arranged by local agencies). In general, this knowledge has been acquired progressively, while developing the offer (e.g. when at the origin were clients demanding a wedding ceremony in a new destination). Given the plans of further expansion there is a clear need for more market knowledge.

On the other hand, the market commitment is minimal. The firm has no investment abroad (irreversible or reversible). Only expenditure to arrange the offer (sometimes including important travel expenses) and developing the company's website in English may be classified as sunk costs.

Intangible assets The essential intangible asset propelling the whole activity of 5 Events based is the know-how about the wedding procedures in foreign destinations on knowledge management

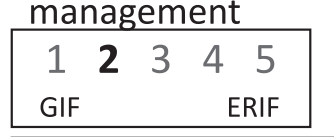
(and key local relationships in some destinations). Still, 5 Events has no monopoly in this area. Moreover, it was the deliberately chosen strategy of firm's development that has induced accumulation of this asset, and not the other way round.

Value creation sources

5 Events' products are not very innovative. There is neither a lot \begin{tabular}{lllll|}
1 & 2 & 3 & 4 & 5
\end{tabular} of space for product differentiation. However, 5 Events bases its competitive advantage on high quality offer, exclusive local relationships in some destinations, and excellent relationships with customers. Still, the value creation capabilities are not exceptional.

\begin{tabular}{|c|c|}
\hline & Strategic focus \\
\hline Trategy & $\begin{array}{l}\text { The company has very quickly based its strategy on the organization of } \\
\text { weddings abroad in a growing number of destinations. This resource } \\
\text { seeking in foreign markets is clearly a highly proactive international } \\
\text { strategy. Moreover, the choice of destinations has been mainly }\end{array}$ \\
\hline & and not by the psychic distance (except for Greece, which has been \\
\hline & chosen also for LW's prior experience). Still, the founder admits that \\
\hline & $\begin{array}{l}\text { facilitate a further expansion (new destinations, new clients). On the } \\
\text { projects (weddings for foreigners in Poland and planned weddings for } \\
\text { foreigners abroad) are given secondary strategic priority. }\end{array}$ \\
\hline
\end{tabular}




\section{Selection,} orientation, and relationships with customers and suppliers

\begin{tabular}{|lrrrr|}
\hline 1 & 2 & 3 & 4 & 5 \\
GIF & & & ERIF \\
\hline
\end{tabular}

5 Events operates in a niche market, with a broad and spread customer group (in the case of its main activity of weddings abroad for Poles). The customers usually look for a high quality product, price being of lesser importance. Hence LW's great effort to supply a perfect customer service as well as a premium and unique offer. The latter requires an original and careful choice of foreign suppliers and constantly propels to new foreign markets research. In many cases, the research is done by LW herself in order to minimize the risk. Still, this doesn't exclude using trustworthy intermediaries (e.g. local agencies). Moreover, the bulk of 5 Events turnover comes from the agency sales of package holidays accompanying the wedding ceremonies arranged by 5 Events.

$\begin{aligned} & \text { Strategic } \\
& \text { flexibility }\end{aligned}$
\begin{tabular}{|lllll|}
\hline 1 & 2 & 3 & 4 & $\mathbf{5}$ \\
GIF & & & ERIF \\
\hline
\end{tabular}

The firm's flexibility to adapt to new clients demands and changing external conditions is high, as the market commitment is relatively very low. LW has also demonstrated capabilities to seize opportunities and to manage a structural change (e.g. using weddings abroad to boost the agency sales of packages holidays, transforming into Internet tour operator, actively searching for new business contacts, hiring new collaborators, expanding its offer for international clients).

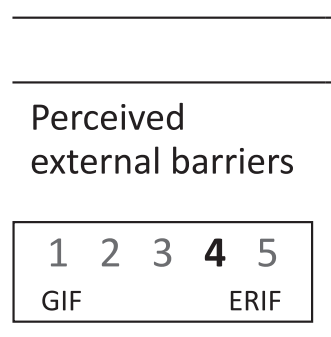

\section{External environment}

External barriers to internationalization of 5 Events perceived by LW are mainly a complexity of weddings formalities and a lack of right local partners in many destinations (and to a much lesser degree intercultural differences). On the other hand, the competition in the Polish market of weddings abroad is not perceived as an impediment (in contrast to the competition pressure in England in perspective of 5 Events' projects of entering this market). Surprisingly, LW finds more challenges to running a business in Poland in general than to her international activities. Still, she admits that this relative courage is also a result of her accumulated experience.

Perceived external incentives

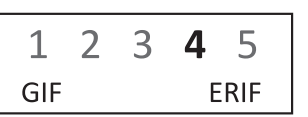

In the case of 5 Events the strongest incentive to internationalization has been the strong competition in the travel agency market in Cracow. It has forced LW to search for a new strategy and made her look for resources directly in the foreign markets. The firm has not used any public support for its activity (neither in general, nor for the internationalization). Even if there are many forms of such support available for SMEs in Poland, LW finds them too complicated and time consuming. The industry of tour operators in general, and weddings abroad in particular are highly internationalized. The specialization of 5 Events in a niche market requires a wide-ranging offer and hence propels a further internationalization.

Evidently, concerning the founder's characteristics, 5 Events matches the standard pattern of ERIF very close. One year after the founding the entrepreneur shifted the business strategy to sourcing in foreign markets. It was relatively easy given the founder's impressive prior international experience. It has also turned out to be successful, while LW has devoted all her energy and resources to this goal. LW has also used and built up her business network, which in many cases was essential to enter new markets. 
Regarding the organizational capabilities, the picture is quite different and 5 Events does not present typical features of an ERIF - it has no great commitment to the foreign markets (neither current nor planned), and no exceptional intangible monopolistic assets assuring high value creation capabilities. The unique source of monopolistic advantage are high quality client service, some local relationships, and know-how about foreign markets (wedding formalities). The latter has been accumulated progressively when entering new destinations. All of this is more in line with stage models than ERIF. This pattern seems to result largely from the specificities of this nichemarket.

On the other hand, the attributes of the strategic focus point to the ERIF model of internationalization. 5 Events has proven a highly proactive and flexible attitude in its hitherto internationalization. And even if the firms enters into new foreign markets progressively, the psychic distance or gradual process of learning through experience are not important issues. The factors slowing down the internationalization in this case are clearly limited human resources and a very careful choice of foreign suppliers and intermediaries in order to minimize the risk and assure a high quality offer.

The attributes of external environment indicate rather an ERIF model of internationalization as LW perceives hardly any major obstacles to her further internationalization plans. However, the issue of external antecedents is quite specific in the case of 5 Events. Or, when LW changed the cap and bet on weddings abroad to boost her agency sales of packages holidays, she entered a highly internationalized niche market. This is a powerful factor pushing towards seeking resources in new markets. On the other hand, there are no such obvious forces when considering 5 Events other transnational projects (weddings in Poland for foreigners, planned weddings abroad for foreigners). While the current internationalization is mainly strategy driven (perfectly in line with ERIF model), the probable future internationalization pattern is not predetermined by the market.

Generally, the attributes in the case of 5 Events point to ERIF internationalization pattern, which is in concordance with the empirical classification. In fact, the company case fits very well the original definition of INV proposed by Oviat and McDougall (1994, p.49): "a business organization that, from inception, seeks to derive significant advantage from the use of resources and the sale of outputs in multiple countries".

On the whole, the general framework of international patterns differentiation seems to suit 5 Events quite well, with the notable exception of organizational capabilities. This category of attributes clearly requires an important adaptation to the specificities of the industry. To the lesser extent 
also external environment attributes could be more tailored to the business characteristics.

\section{Conclusion}

For many years firms internationalized mainly incrementally, gradually learning from foreign markets and foreign networks. The researchers have thus proposed stage model theories. Yet, when the economic globalization accelerated in the 1980s, a new phenomenon of early and rapidly internationalizing enterprises was observed and new models to explain this internationalization pattern proposed. Thanks to theoretical and empirical advances in the field, today a lot is already known about antecedents and process of both kinds of SME internationalization. However, the research has been focused mainly on outward internationalization and more in manufacturing industry than in services (and is almost non existent in the tourism industry). Thus, the paper has undertaken an exploratory research to verify to what extent the common framework of analysis may explain an internationalization path of SMEs in the tourism sector. Consequently, the internationalization process and its antecedents in a case of a small tour operator operating in a niche market of weddings abroad have been studied.

Concerning the internationalization antecedents of the sample business, the pattern matching largely confirmed the empirical classification indicating the general appropriateness of the common framework of differentiation between rapidly and gradually internationalizing SMEs in the case of a tour operator. However, it has also shown the need for an important industry adaptation in the case of attributes concerning organization capabilities, and (to a lesser extend) external environment.

In terms of the internationalization process, the research has confirmed the approach of Fletcher (2001), as different forms of internationalization are interlinked, parallel and reinforcing each other. In particular, an early and rapid internationalization through imports may lead to a gradual internationalization through exports. The former may result from a proactive attitude, be strategy driven, and implied by characteristics of the market and product (well in line with models of ERIF). The latter, however, may result from a more passive attitude, a kind of letting the windows of opportunity open, without committing many resources (more in line with models of gradually and slowly internationalizing firms).

Therefore, the main implications of this study for further research are twofold - not only there is a need to adapt the general framework to the industry features (in particular in terms of organization capabilities) but 
such a further research should also take into account the heterogeneity of international activities (in terms of their antecedents and process). Even if a firm is born global, its further internationalization may well be incremental in nature.

\section{References}

Agndal, H., Elbe, J. (2007). The internationalization process of small and medium-seized Swedish tourism firms. Scandinavian Journal of Hospitality and Tourism, 7 (4), 301-327.

Andersen, O. (1993). On the internationalization process of firms: A critical analysis. Journal of International Business Studies, 24(2), 209-231.

Anderson, E.W., Weitz, B. (1992). The use of pledges to build and sustain commitment in distribution channels. Journal of Marketing Research, 29(1), 18-34.

Anderson, S., Wictor, I. (2003). Innovative internationalisation in new firms: Born globals - the Swedish case. Journal of International Entrepreneurship, 1(3), 249-276.

Antoncic, B., Hisrich, R. D. (2000). An integrative conceptual model. Journal of Euromarketing, 9(2), 17-35.

Aspelund, A., Moen, O. (2001), A generation perspective on small firm internationalization: From traditional exporters and flexible specialists to born globals. In: C. Axinn and P. Matthyssens (Eds.) Reassessing the Internationalization of the Firm. Advances in International Marketing, 11, (pp.197-225). Emerald Group Publishing Limited.

Autio, E., Sapienza, H., Almeida, J. (2000), Effects of Age at Entry, Knowledge Intensity, and Imitability on International Growth. Academy of Management Journal, 43 (5), 909-924.

Bell, J., McNaughton, R., Young, S., Crick, D. (2003). Towards an integrative model of small firm internationalisation. Journal of International Entrepreneurship, 1(4). 339-362.

Bilkey, W., Tesar G. (1977). The export behavior of smaller-sized Wisconsin manufacturing firms. Journal of International Business Studies, 8(1), 9398.

Bonaccorsi, A. (1992). On the relationship between firm size and export intensity. Journal of International Business Studies, 23(4), 605-635.

Caves, R.E. (1971). International corporations: The industrial economics of foreign investment. Economica, 38(149), 1-27.

Cavusgil, S. (1980). On the internationalisation process of firms. European Research, 8(6), 273-281.

Cavusgil, S. (1984). Differences among exporting firms based on their degree of internationalization. Journal of Business Research, 12(2), 95-208. 
Chetty, S., Blankenburg-Holm, D. (2000). Internationalisation of small to medium-size manufacturing firms: a network approach. International Business Review, 9(1), 77-93.

Chetty, S., Campbell-Hunt C. (2003). Paths to internationalisation among small-to medium-sized firms: a global versus regional approach. European Journal of Marketing, 37(5/6), 796-820.

Chetty, S.,Campbell-HuntC. (2004).Astrategicapproach tointernationalization: a traditional versus a "Born-Global" approach. Journal of International Marketing, 12(1), 57-81.

Coviello, N. (2006). The network dynamics of international new ventures. Journal of International Business Studies, 37(5), 713-731.

Coviello, N., McAuley, A. (1999). Internationalisation and the smaller firm: a review of contemporary empirical research. Management International Review, 39(3), 223-256.

Coviello, N., Munro H. (1995). Growing the entrepreneurial firm: Networking for international market development. European Journal of Marketing, 29(7), 49-61.

Coviello, N., Munro H. (1997). Network relationships and the international process of small software firms. International Business Review, 6(4), 361386.

Covin, J. G., Slevin, D. P. (1989). Strategic Management of small firms in hostile and benign environments. Strategic Management Journal, 10(1), 75-87.

Creswell, J.W. (2003). Research Design: Qualitative, Quantitative, and Mixed Methods Approaches. (2nd ed.). Thousand Oaks: Sage Publications.

Czinkota, M.R. (1982). Export Development Strategies: US promotion policies. New York: Praeger Publishers.

Davidsson, P., Delmar, F., Wiklund, J. (2006). Entrepreneurship as Growth: Growth as Entrepreneurship. In: P. Davidsson, F. Delmar, and J. Wiklund, (Eds.) Entrepreneurship and the Growth of Firms (pp. 21-38). United Kingdom, England, Cheltenham: Edward Elgar Publishing.

Dimitratos, P., Johnson. J., Slow, J., Young, S. (2003). Micromultinationals: new types of firms for the global competitive landscape. Management International Review, 39(3), 223-256.

Dimitratos, P., Plakoyiannaki, E., Pitsoulaki, A. (2010). The Global smaller firm in international entrepreneurship. International Business Review, 19(6), 589-606.

Dunning, J.H. (1981). International Production and the Multinational Enterprise. London: Allen and Unwin.

Dwyer, F.R, Schurr, P.H., Oh, S. (1987). Developing buyer-seller relationships. Journal of Marketing, 51(2), 11-27.

Ellis, P. (2000). Social ties and foreign market entry. Journal of International Business Studies, 31(3), 443-469.

Fayed, H., Fletcher, J. (2002). Globalisation of economic activity: issues for tourism. Tourism Economics, 8(2), 207-230. 
Fillis, I. (2001). Small firm internationalisation: an investigative survey and future research directions. Management Decision, 39(9), 767-783.

Fletcher, R. (2001). A holistic approach to internationalisation. International Business Review, 10 (1), 25-49.

Ford, I.D., Leonidou, L.C. (1991). Research Developments in International Marketing: A European Perspective. In: S.J. Paliwoda (Ed.), New perspectives on international marketing (pp. 3-32). London: Routledge, Gabrielsson, M., Kirpalani V.H. (2004). Born Globals: how to reach new business space rapidly. International Business Review, 13(5), 555-571.

Hessels J. (2008). International Entrepreneurship: An Introduction, Framework and Research Agenda, Scales Research Reports H200823, EIM Business and Policy Research.

Hjalager, A.M. (2007). Stages in the economic globalization of tourism. Annals of Tourism Research, 43(2), 437-457.

Hymer, S.H. (1976). The International Operations of National Firms: A Study of Foreign Direct Investment. Cambridge, MA: MIT Press.

Ibeh, K.I.N. (2006). Internationalisation and the Smaller Firm. In: S. Carter and D. Evans (Eds.), Enterprise and Small Business. Second Edition (pp. 465484). Harlow: Financial Times and Prentice Hall.

Johanson, J., Vahlne J. (1977), The internationalization process of the firm - a model of knowledge development and increasing foreign market commitments. Journal of International Business Studies, 8(1), 23-32.

Johanson, J., Vahlne J. (1990), The mechanism of internationalisation. International Marketing Review, 7(4), 11-24.

Johanson, J., Vahlne J. (2009). The Uppsala internationalization process model revisited: from liability of foreignness to liability of outsidership. Journal of International Business Studies, 40(9), 1411-1431.

Johanson, J., Wiedersheim-Paul F. (1975). The internationalization of the firm- four cases. Journal of Management Studies, 12(3), 305-322.

Johnson, C., Vanetti, M. (2005). Market Developments in the hotel sector in Eastern Central Europe. Advances in Hospitality and Leisure, 1, 153-175.

Kirzner, I. (1979). Perception, Opportunity, and Profit. Chicago: University of Chicago Press.

Knight, G.A., Cavusgil, S.T. (1996). The born global firm: a challenge to traditional international theory. Advances in International Marketing, 8 , 11-26.

Knight, G.A., Cavusgil, S.T. (2004). Innovation, organization capabilities, and the born-global firm. Journal of International Business Studies, 35(2), 124-141.

Kundu, S. K., Katz, J.A. (2003). Born-international SMEs: Bi-level impacts of resources and intentions. Small Business Economics, 20(1), 25-47.

Lanfant, M.F. (1995). International Tourism, Internationalization and the Challenge to Identity. In: M.F. Lanfant, J.B. Allock and E.M. Bruner (Eds.) International Tourism: Identity and Change (pp. 24-43). London: Sage. 
Leiblein, M., Reuer, J. (2004). Building a foreign sales base: the roles of capabilities and alliances for entrepreneurial firms. Journal of Business Venturing, 19(30), 285-307.

Leonidou, L., Katsikeas, C. (1996). The export development process: an interrogative review of empirical models. Journal of International Business Studies, 27(3), 517-551.

Leonidou, L.C., Katsikeas, C.S. (1997). Export information sources: the role of organizational and internationalization influences. Journal of Strategic Marketing, 3(2), 1-23.

Lu, J.W., Beamish, P.W. (2001). The internationalization and performance of SMEs. Strategic Management Journal, 22 (6/7), 565-586.

Lumpkin, G.T., Dess, G.G. (1996). Clarifying the entrepreneurial orientation construct and linking it to performance. The Academy of Management Review, 21(1), 135-172.

Madsen, T.K, Rasmussen, E.S., Servais, P. (2000). Differences and Similarities Between Born Globals and Other Types of Exporters. In: A. Yaprak and $\mathrm{H}$. Tuted (Eds.) Globalization, the Multinational Firm, and Emerging Economies (Advances in International Marketing, 20), (pp. 247-265). Amsterdam: JAI Press/Elsevier.

Madsen, T.K. (2013). Early and rapidly internationalizing ventures: similarities and differences between classifications based on the original international new venture and born global literatures. Journal of International Entrepreneurship, 11(1), 65 - 79.

Madsen, T.K., Servais, P. (1997). The internationalization of Born Globals: an evolutionary process. International Business Review, 6(2), 561-583.

Martin, X, Swaminathan, A., Mitchell, W. (1998). Organizational evolution in the interorganizational environment: incentives and constraints on international expansion strategy. Administrative Science Quarterly, 43 (3), 566-601.

McAuley, A. (1999). Entrepreneurial instant exporters in the Scottish Arts and Crafts Sector. Journal of International Marketing, 7(4), 67-82.

McDougal, P. (1989). International versus domestic entrepreneurship: new venture strategic behavior and industry structure. Journal of Business Venturing, 4, 387-399.

McDougall, P., Oviat, B.M., Shrader, R.C. (2003). A comparison of international and domestic new ventures. Journal of International Entrepreneurship, 1(1), 59-82.

McDougall, P., Shane, S., Oviat, B.M. (1994). Explaining the formation of international new ventures. Journal of Business Venturing, 9(6), 469-487.

Moen, O. (2002). The Born Globals: a new generation of small European exporters. International Marketing Review, 19(2), 156-175. 
Moen, O., Servais, P. (2002). Born Global or Gradual Global? Examining the export behavior of small and medium-sized enterprises. Journal of International Marketing, 10 (3), 49-72.

Moini A.H. (1995). An inquiry into successful exporting: an empirical investigation using a three-stage models. Journal of Small Business Management, 33(3), 9-25.

Ohlin, B. (1933). Interregional and International Trade. Cambridge, Mass.: Harvard University Press.

Oviat B.M., McDougall, P. (1997). Challenges for internationalization process theory: the case of international new ventures. Management International Review, 37(2), 85-99.

Oviat B.M., McDougall, P. (2005). Defining International entrepreneurship and modeling the speed of internationalization. Entrepreneurship Theory and Practice, 29(5), 537-553.

Oviat M.B., McDougall, P. (1995). Global Start-ups: entrepreneurs on a worldwide stage. Academy of Management Executive, 9(2), 30-43.

Oviatt, B.M., McDougall, P. (1994), Toward a Theory of international new ventures. Journal of International Business Studies, 25(1), 45-64.

Reid, S. (1981). The decision-maker and export entry and expansion. Journal of International Business Studies, 12(2), 101-112.

Rennie, M.W. (1993). Global Competitiveness: Born Global. The McKinsey Quarterly, 4(4), 45-52.

Rialp, A, Rialp, J., Urabano, D. Vaillant, Y. (2005). The born-global phenomenon: a comparative case study research. Journal of International Entrepreneurship, 3(2), 133-171.

Ricardo, D. (1817). On the Principles of Political Economy and Taxation. London: John Murray.

Sharma, D., Johanson, J. (1987). Technical consultancy in internationalisation. International Marketing Review, 4 (4), 20-29.

Sharma, D. D., Blomstermo, A. (2003). The internationalization process of Born Globals: A network view. International Business Review, 12(6), 739-753.

Shaw, G., Williams, A.M. (2004). Tourism and tourism spaces. London: Sage.

Smith, A. (1776). An inquiry into the Nature and Causes of the Wealth of Nations. London: Methuen and Co.

Strauss, A., Corbin, J. (1990). Basics of Qualitative Research: Grounded Theory Procedures and Techniques. Newbury Park. CA: Sage Publications, Inc.

Vernon, R. (1966). International investment and international trade in the product cycle. Quarterly Journal of Economics, 80(2), 190-207.

Walsham, G. (1995). Interpretive case studies in is research: nature and method. European Journal of Information Systems, 4(2), 74-81.

Weerawardena, J., Mort, G.J., Liesch, P.W., Knight, G. (2007). Conceptualizing accelerated internationalization in the born global firm: a dynamic capabilities perspective. Journal of World Business, 42(3), 294-306. 
Welch, D. E., Welch, L. S. (1996). The Internationalisation process and networks: a strategic management process. Journal of International Marketing, 4(3), 11-26.

Williams, A.M., Shaw, G. (2011). Internationalization and innovation in tourism. Annals of Tourism Research, 38(1), 27-51.

Williamson, O. E. (1973). Markets and hierarchies: Analysis and anti-trust implications. American Economic Review, Papers and Proceedings 63(2), 316-325.

Yin, R. (1994). Case Study Research: Design and Methods (2nd ed.). Beverly Hills, CA: Sage Publishing.

Zahra, S.A. (2005). A theory of international new ventures: a decade of research. Journal of International Business Studies, 36(1), 20-28.

Zahra,S.A.,George,G. (2002). Absorptivecapacity: areview, reconceptualization and extension. Academy of Management Review, 27(2), 185-203.

Zahra, S.A., Hayton, J., Marcel, J., O'Neill, H. (2001). Fostering entrepreneurship during international expansion: managing key challenges. European Management Journal, 19(4), 359-69.

Zahra, S.A., Kuratko, D., Jennings, D. (1999). Entrepreneurship and the acquisition of dynamic organizational capabilities. Entrepreneurship Theory \& Practice, 23(3), 5-10.

\section{Abstrakt (in Polish)}

Dzisiaj wiele już wiadomo o wzorcach internacjonalizacji małych i średnich przedsiębiorstw (MSP). Jednak dotychczasowe badania skupiały się głównie na internacjonalizacji poprzez eksport oraz dotyczyły bardziej przemysłu niż sektora usług (i w bardzo nikłym stopniu internacjonalizacji firm turystycznych). Dlatego też niniejszy artykut podejmuje wstępne badania w celu zweryfikowania, w jakim stopniu ogólnie stosowane ramy analizy sq przydatne $w$ zrozumieniu ścieżki internacjonalizacji MSP sektora turystycznego. W tym celu dokonane zostaje studium przypadku małego tour operatora w Polsce działajqcego w niszowym segmencie ślubów za granicq. Badanie zestawia charakterystykę internacjonalizacji firmy z ustaleniami dwóch głównych ujęć teoretycznych internacjonalizacji MSP: modelami stopniowej internacjonalizacji (tzw. modele behawioralne) oraz modelami wczesnej i szybkiej internacjonalizacji (firmy zwane "urodzonymi globalistami").

Główne wnioski badania sq dwojakie. Po pierwsze, nawet, jeśli powszechnie stosowane ramy analizy całkiem dobrze służq analizie przypadku małego tour operatora, to jednak istnieje wyraźna potrzeba adaptacji tych ram do specyfiki sektora (zwłaszcza w przypadku zdolności organizacyjnych). Po drugie, dalsze badania powinny uwzględnić także niejednorodność międzynarodowych działań firmy (w zakresie ich czynników sprawczych jak i przebiegu). Nawet, jeśli firma rodzi się globalistq, jej dalsza internacjonalizacja może jednak przebiegać stopniowo. W szczególności, wczesna i szybka internacjonalizacja poprzez import może prowadzić do stopniowej, etapowej internacjonalizacji przez eksport. Ten pierwszy rodzaj (i etap) działalności międzynarodowej firmy może wynikać z aktywnej postawy wobec internacjonalizacji, być istota 
strategii firmy i wiq̨zá się z charakterystykq rynku i produktu (zgodnie z modelami wczesnej i szybkiej internacjonalizacji). Natomiast drugi rodzaj (i etap) działalności międzynarodowej może wynikać z bardziej biernej postawy i wiqzać się z minimalnym zaangażowaniem zasobów (zgodnie z modelami internacjonalizacji stopniowej i powolnej).

Słowa kluczowe: MSP, internacjonalizacja, modele etapowe internacjonalizacji, modele behawioralne, urodzeni globaliści, born globals, przedsiębiorczość międzynarodowa, sektor turystyczny, tour operator, rynek niszowy. 